\title{
Impact of Blended Approach on Second Year Home Economics Students' Biology Practical Achievement in Two Districts of Oti Region, Ghana
}

\author{
S. Klu ${ }^{1}$, Y. Ameyaw ${ }^{1}$, W. K. Hordzi ${ }^{1}$
}

${ }^{1}$ Department of Biology Education, Faculty of Science Education, University of Education, Winneba, Ghana

\begin{abstract}
The study determines the impact of Blended Approach as a pedagogical tool in teaching Second Year Home Economics students in three schools obtained from two districts within Oti Region. The selection of the three schools was based on the fact that the schools had at least two Home Economics Second Year classes and as well showed poor performance in biology practicals during the diagnostic stage of the study. In all, 164 Second Year Home Economics students representing six intact classes with three experimental groups and three control groups were sampled from the three schools. The research design employed was quasi-experimental design using pretest-posttest nonequivalent design. A 30item test captioned as 'SKbBPCT' and 'HESAPBT' for pretest-posttest respectively were administered on students to generate data for analysis. Data generated was analysed using ANCOVA in SPSS version 25. The study revealed that Bleeded Approach which involved the use of TLA and MLA to teach Home Economics Second Year students biology practicals had positive significant impact on their achievement scores.
\end{abstract}

Keywords: Multimedia Laboratory Approach (MLA), Traditional Laboratory Approach (TLA), Opportunity-to-learn (OTL) Practical Content Knowledge (PCK), Practical Pedagogical Knowledge (PPK), Teacher-Student Learning Support (TSLS), Home Economics Students Achievement in Practical Biology Test (HESAPBT), Students Knowledge in basic Biology Practical Concept Test (SKbBPCT)

\section{Introduction}

In the history of education, science education is distinctive with pedagogical emphasis on values such as experimentation, which largely relies on physical facilities like the laboratory (Huang, 2006). Due to the importance of laboratory work in science, it has long been accepted as an integral part of science education (Häse, Roch \& Aspuru-Guzik, 2019; Dechsri, Jones \& Heikkmen, 1997).

According to Trowbridge, Bybee and Powell (2004), science teaching without laboratory experience is not really science. To this, science curriculum innovations and reforms over the years were characterised by the attempts to incorporate more practical oriented and investigative activities into science classes (Cunningham \& Kelly, 2017; Clark, 2003). The fundamental aim of incorporating practical oriented and investigative activities into science classes, according to Duran and Ozdemir (2009), is not growing up every student to be a pure scientist, but providing them with a multidimensional thinking as scientists do, so that they would be able to produce scientific knowledge as well as learn science by doing and experiencing.

Supiano (2018) noted that traditional method of teaching biology only deepens students' inequality in knowledge acquisition. That is all students acquire the same information presented orally at the same pace without any dialogue and practical integration (Chism, Jones, Macce \& Mountford, 1989; Johnson, Johnson \& smith, 1991). In addition, the traditional instructional approach assumes that students are auditory learners and have high memory capacities (Johnson, Johnson \& Smith, 1991). A teacher, who therefore adopts this instructional approach which is mainly teacher-centered and focuses on talks mainly (auditory cue) without practical integration, may only appeal to one category of students and not all students.

In Ghana, various governments continue to place strong emphasis on the role of ICT in transforming the country's economy since 1995, when Ghana became the first country in Sub Saharan Africa to get full internet connectivity. This was captured in the country's medium-term development plans including the Ghana Poverty Reduction Strategy Paper (GPRS I\&II) and the Education Strategic Plan 2003-2015 that recognizes the use of ICT as a vehicle for reaching out to the poor in Ghana (Government of Ghana, 2003). The Ghanaian Parliament in 2004 legislated Ghana's ICT for Accelerated Development (ICT4AD) policy into law with an operational life span of between 15 to 20 years. Again, Ministry of Education in (2007) produced an ICT in education policy for Ghana to integrate ICTs in schools.

In spite of all these initiatives, there are some challenges which are revealed by research findings that account for the difficulty in the incorporation of ICT at all levels of education as expected by the ICT in education policy. Notable among them is teachers' lack of confidence to use computer as an instructional 
tool (Agyei \& Voogt, 2011a, 2011b; British Educational Communications and Technology Agency, 2004) because of lack of enough training to use computers as supportive instructional tools ever since it has not been profound in teacher professional training.

Besides, some educators are of the view that making technology a part of teaching and learning process is expensive (New Partnership for Africa's Development [NEPAD], 2001). These educators argue that ICT machines need to be bought, and also frequently malfunction ones need to be serviced. If a teachers' presentation or learners' activities are structured around a machine that may not always work, confidence in the machine may be shattered, and this would result in a distortion in teaching and learning.

Although, the concerns raised by some educators may be justifiable, multimedia instruction is increasingly gaining root and becoming a legitimate form of instruction in the world because of its enormous advantages in teaching and learning. This implies that multimedia education has come to stay, and we can only embrace it to improve teaching. According to Kareem (2018), there is the need to adopt and use multimedia approach in teaching biology because it has positive impact on students learning outcomes. Again, Black (2010) also revealed that the use of multimedia approach cannot be ignored in our schools because students are no longer the same target population for which our educational systems were designed a few decades ago.

To this, globally, there has been a re-conception of education, which ruptured traditional assumptions and educational models by Cognitive scientists. The exploration of cognitive scientists into the emergent learning formats that might meet the needs of a 'participative learner', introduced the blended instructional approach of teaching which goes beyond the traditional view of 'classroom instruction', and that of education as the 'transmission of knowledge' within the constraints set by a curriculum. According to Singh and Reed (2001), blended approach is the transfer of "right" skills to the "right" person at the "right" time by matching the "right" learning technologies with the "right" learning style for the purpose of achieving improved learning outcomes.

A body of literature on blended instructional approach which combines traditional approach with multimedia approach has provided evidence to contribute significantly to High School Students biology academic achievements (Nurhikmah, Tahmir, Junda, \& Bena, 2018; Boelens, Van Laer, De Wever \& Elen, 2015; Graham, 2013; Al- Qahtani \&
Higgins, 2013 \& Ümit \& Hasan, 2012). However, missing from literature are the investigations to validate the efficacy of blended approach in teaching biology practicals to students particularly in Ghana.

The performance of Second Year Home Economics students in two districts of Oti Region was poor at the end of a preliminary study which sought to assess their performance in biology practicals. To this end, this study developed Blended Approach which involved the use of Multimedia Laboratory Approach (MLA) and Traditional Laboratory Approach (TLA) to teach biology practicals to Second Year Home Economics Students and determine its efficacy.

Therefore, this study finds out the impact of Blended Approach on second year Home Economics Students' Biology practical achievement in two Districts of Oti Region, Ghana. Specifically, the study determined the impact of:

1) Traditional Laboratory Approach on Second Year Home Economics students' performance in three topics of biology practicals in two districts of Oti Region.

2) Multimedia Laboratory Approach on Second Year Home Economics students' performance in three topics of biology practicals in Kadjebi and Jasikan Districts.

3) the Blended Approach (combination of TLA and MLA) on Second Year Home Economics students'performance in three topics of biology practicals in two districts of Oti Region.

\section{Scope of the Study}

The study focused on Second Year Home Economics students from three schools located in two districts of Oti Region Ghana. These schools were considered because students were not engaged in incessant biology practicals, and therefore, their performance in biology practicals were not encouraging, and that negatively affected their general performance in biology.

\section{Research Questions}

The following research questions directed the study:

1) To what extent did TLA improve the performance of Second Year Home Economics students in three topics of biology practicals in two Districts of Oti Region?

2) To what extent did MLA improve the performance of Second Year Home Economics students in three topics of biology practicals in two districts of Oti Region?

3) What is the effect of the Blended Approach (combination of TLA and MLA) on Second Year Home Economics students' 
performance in three topics of biology practicals in two Districts of Oti Region?

\section{Hypotheses}

$\mathrm{Ho}_{1}$ : There is no statistically significant difference among the mean achievement scores of Second Year Home Economics students taught Biology practicals using TLA in Microscope, Orientation, Section \& Body Symmetry and Biological Drawing.

$\mathrm{Ho}_{2}$ : There is no statistically significant difference among the mean achievement scores of Second Year Home Economics students taught Biology practicals using MLA in Microscope, Orientation, Section \& Body Symmetry and Biological Drawing.

$\mathrm{Ho}_{3}$ : There is no statistically significant difference among the mean achievement scores of Second Year Home Economics students taught Biology practicals using a combination of MLA and TLA in Microscope, Orientation, Section \& Body Symmetry and Biological Drawing.

\section{Conceptual Framework}

The Blended Approach (BA) conceptual framework adapted three variables of the opportunity-to-learn (OTL) variables which were first developed by Stevens (1993). According to Stevens (1993), four variables which include Content Coverage, Content Exposure, Content Emphasis and Quality of
Instructional Delivery have positive influence on students' performance.

To this, the study focused on Content Exposure variable, which comprised Traditional Laboratory Approach and Multimedia Laboratory Approach as independent variables, but blended to teach Home Economics students selected topics in biology practicals (Content Coverage). The framework also took cognizance of students Science (Biology) Process Skills (SPS) and Motivation as covariates to increase the accuracy of the treatment meted out to the dependent variable (students' practical performance). Both Science (Biology) Process Skill and student Motivation are classified as Content Emphasis variables.

Moreover, the framework identified teacher characteristics such as professional knowledge in practicals, beliefs towards practicals, ICT skills, qualification and experience as variables that affect the independent variables (Content Exposure variables) and consequently the dependent variable (students' practical performance) during practical lessons.

The framework also considered two extraneous variables; students Learning Styles (LSs) and their External Environment (EE) which undoubtedly affects students Biology practical experience and attitude. 


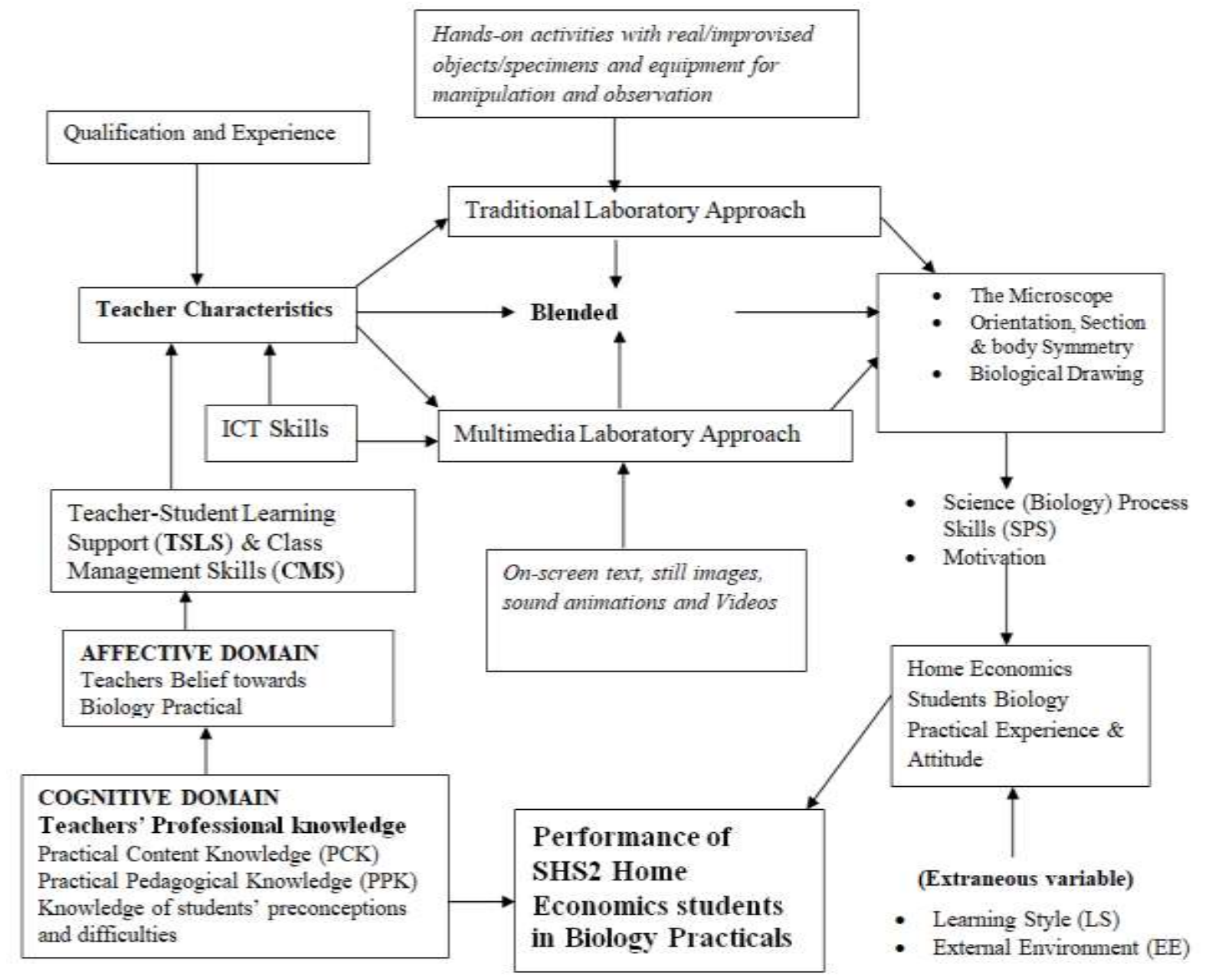

\section{Research Methodology \\ Research Design}

The study adopted a quasi-experimental design using pretest-posttest nonequivalent group design. According to White and Sabarwal (2014), this design is one of the most widespread in educational research and involves an experimental group and a control group, both given pretest and posttest, but in which the control group and the experimental group do not have pre-experimental sampling equivalence. Rather, the groups constitute naturally assembled collectives such as classrooms, as similar as availability permits but yet not so similar that one can dispense with a pretest. Again, the assignment of $\mathrm{X}$ to one group or the other is assumed to be random and under the experimenter's control.

Since the purpose of the study was to determine the efficacy of the Blended Approach in teaching biology practicals to Second Year students and at the same time not distorting academic activities as outlined by the schools, this design was considered to be the best.

\section{Sample Size}

The sample size comprised 164 Home Economics Second Year students selected from three schools. By this, six intact classes with minimum and maximum class sizes of 18 and 32 respectively were selected.

The selection of the three schools was such that the schools had at least two Home Economics Second Year classes as well as showed poor performance in biology practicals during a diagnostic test (HESPBT). Again, the selection of both experimental and control groups was based on the fact that, the groups had mean scores that were close but not equivalent at the end of a pretest that was administered. 
Table 1: Sample frame for the study

$\begin{array}{ccc}\text { School } & \begin{array}{c}\text { No. of Intact } \\ \text { Classes }\end{array} & \begin{array}{l}\text { Treatment } \\ \text { Groups }\end{array} \\ \text { A } & 2 & \mathrm{X}_{3} \\ \text { B } & 2 & \mathrm{X}_{2} \\ \text { D } & 2 & \mathrm{X}_{1} \\ \text { Total } & 6 & \end{array}$

In all, 80 students from three intact classes constituted the experimental group whilst another 84 students from three intact classes constituted the control group. Treatment groups were given specific treatments as described below:

\section{Treatment Group $X_{1}$}

This group was taught using Traditional Laboratory Approach (TLA). By this approach, hands-on activities with real or improvised bio-specimens and equipment for manipulation and observation of processes in the laboratory were employed. Here, students were made to either engage in individual or group practical activities after they had been provided with instructions and relevant demonstrations on the practical activities.

\section{Treatment Group $X_{2}$}

This group was taught using Multimedia Laboratory Approach (MLA). By this approach, biology practical lessons were presented to students using audio-videos with on-screen text, still images, narrations, animations and graphics. Here, students were made to watch videos of the practical lessons and thereafter allowed to ask questions for further clarifications. Also, students had the opportunity to have a replay of sessions of the lessons as they so wish.

\section{Treatment Group $\mathbf{X}_{3}$}

This group was taught using a combination of TLA and MLA. By this instructional approach, students were presented with hands-on materials (either real or improvised) including bio-specimens and equipment. Thereafter, they were made to watch videos of the practical lessons and alongside engaged in the practical activities using the hands-on materials provided. This was done to ensure that there is harmony between the two approaches (TLA and MLA) adopted for this group.

At each stage of the practical activity, the video lessons were paused, and students were allowed to ask questions and also to perform the live practicals with the items provided as they may have observed in the video.

To make sure however that instructional time in all the experimental groups $\left(\mathrm{X}_{1}, \mathrm{X}_{2}\right.$ and $\left.\mathrm{X}_{3}\right)$ were not

\begin{tabular}{|c|c|c|c|}
\hline $\begin{array}{l}\text { Class } \\
\text { Sizes }\end{array}$ & $\begin{array}{l}\text { Control } \\
\text { Groups }\end{array}$ & $\begin{array}{l}\text { Class } \\
\text { Sizes }\end{array}$ & $\begin{array}{c}\text { Total } \\
\text { No. of } \\
\text { students } \\
\text { selected }\end{array}$ \\
\hline 30 & $\mathrm{X}_{\mathrm{B}}$ & 30 & 60 \\
\hline 18 & $\mathrm{X}_{\mathrm{A}}$ & 24 & 42 \\
\hline 32 & $\mathrm{X}_{\mathrm{C}}$ & 30 & 62 \\
\hline 80 & & 84 & 164 \\
\hline
\end{tabular}

prolonged, only contents outlined in the lesson plans were strictly considered and taught.

\section{Control of Extraneous Variables}

The study adopted the following procedures as proposed by Umoke and Nwafor (2014) to ensure that extraneous variables which may introduce bias into the study were largely controlled.

\section{(a) Teacher variable:}

In order to control the errors which may have arisen as a result of teacher differences, the researcher taught the groups instead of the regular class teachers. Meanwhile, teachers were trained to use the various approaches in teaching students after the research was conducted.

\section{(b) Inter-group variable:}

Because intact classes were used for the study, it implied that initial equivalence as would have been achieved by simple random sampling was impossible for the treatment groups. With this, the study controlled the incongruity that could have arisen in comparing the effect of the treatments by using Analysis of Co-Variance (ANCOVA). By ANCOVA, the pretest scores were treated as covariates.

\section{(c) Student- Student Interactions:}

To deal with this extraneous variable, the study did not select treatment and control groups for the same approach from the same school because they could mix up and exchange ideas which would introduce error into the data collected. Again, this helped to eliminate the possibility of a John Henry Effect (a spirit of competition triggered among students on realizing that they are being used for experiment and required comparison at the end).

\section{Data Collecting Instruments}

\section{a) Students' Knowledge in basic Biology Practical Concept Test (SKbBPCT)}

This instrument which was the pretest comprised 30 items classified into 4 sections (A, B, C \& D) and scored 50 marks. The test covered the following Year 1 topics: body symmetry, sections and orientation of specimens; preparation of wet-mount slide; identification of the parts of the microscope and its operation; and biological drawing. These topics were selected because it is believed that students had 

Ghana

already treated them and that their responses would indicate a true picture of their level of performance before treatment.

b) Home Economics Students Achievement in Practical Biology Test (HESAPBT)

This instrument was the posttest which was administered after the treatment to determine the extent to which students have improved in performance. The HESAPBT produced internal consistency reliability estimated value of 0.84 by Cronbach's Alpha method in SPSS version 16.

Since the pretest and posttest items were the same, the posttest (HESAPBT) items were re-shuffled to address the issue of familiarity.

\section{Results and Discussion \\ Research Question 1}

To what extent did TLA improve the performance of Second Year Home Economics students in three topics of biology practicals in two Districts of Oti Region?

This research question was answered using the findings from the statistical analysis of pretest and posttest results of students of School C who were taught biology practicals using Traditional Laboratory Approach (TLA) only. Both mean scores and standard deviations as summarized in Tables 2 and 3 were used to compare students' performance before and after the treatment.

Table 2: Students' performance in SKbBPCs before TLA $(\mathbf{N}=32)$

\begin{tabular}{ccccc}
\hline \multirow{4}{*}{ Pretest } & Variable & Mean & Std. Deviation & Std. Error \\
\cline { 2 - 5 } & M & 3.06 & 1.605 & .284 \\
& OSS & 4.56 & 1.703 & .301 \\
\hline
\end{tabular}

Table 3: Students' performance in SKbBPCs after TLA $(\mathbf{N}=32)$

\begin{tabular}{lcccc}
\hline \multirow{4}{*}{ Posttest } & Variable & Mean & Std. Deviation & Std. Error \\
\cline { 2 - 5 } & M & 10.41 & 1.998 & .353 \\
& OSS & 9.94 & 2.747 & .486 \\
& BD & 8.31 & 2.023 & .358 \\
\hline
\end{tabular}

To answer the corresponding null hypothesis $\left(\mathrm{Ho}_{1}\right)$ which stated that there is no statistically significant difference among the mean achievement scores of SHS2 Home Economics students taught Biology practicals using TLA in Microscope, Orientation,
Section \& Body Symmetry and Biological Drawing, the research performed ANCOVA on posttest scores of students in School ' $\mathrm{C}$ ' as indicated in Table 3.

Table 3: Effect of TLA on students' performance in three topics of biology practicals

\begin{tabular}{|c|c|c|c|c|c|c|}
\hline Source & $\begin{array}{c}\text { Type III Sum of } \\
\text { Squares }\end{array}$ & $d f$ & an Square & $F$ & Sig. & $\begin{array}{l}\text { Partial Eta } \\
\text { Squared }\end{array}$ \\
\hline Corrected Model & $84.225^{\mathrm{a}}$ & 3 & 28.075 & 5.409 & .002 & .150 \\
\hline Intercept & 1892.949 & 1 & 1892.949 & 364.704 & .000 & .799 \\
\hline Pretest & 6.954 & 1 & 6.954 & 1.340 & .250 & .014 \\
\hline Group & 83.370 & 2 & 41.685 & 8.031 & .001 & .149 \\
\hline Error & 477.514 & 92 & 5.190 & & & \\
\hline Total & 9321.000 & 96 & & & & \\
\hline Corrected Total & 561.740 & 95 & & & & \\
\hline
\end{tabular}

The results however revealed an $F(1,95)=8.031$ with a significant value of .001 at 0.05 alpha level. This implies that there is a statistically significant mean difference among the achievement scores of Home Economics students taught biology practical using TLA in Microscope, Orientation, Section \&
Body Symmetry and Biological Drawing. To this, the null hypothesis one $\left(\mathrm{Ho}_{1}\right)$ was rejected and a follow up posttest mean score test which was Tukey post hoc test to locate where the honestly significant difference existed using pairwise comparison was concurrently performed.

Table 4: Tukey Post Hoc Multiple Comparison of Significance of Variable Mean Scores

\begin{tabular}{|c|c|c|c|c|c|c|c|}
\hline \multirow{2}{*}{\multicolumn{2}{|c|}{ Comparisons }} & \multirow{3}{*}{$\begin{array}{c}\text { Mean Difference } \\
.469\end{array}$} & \multirow{3}{*}{$\begin{array}{c}\text { Std. } \\
\text { Error }\end{array}$} & \multirow{3}{*}{$\begin{array}{l}\text { Sig. } \\
.691\end{array}$} & \multicolumn{2}{|c|}{ 95\% Confidence Interval } & \multirow[b]{2}{*}{ Remark } \\
\hline & & & & & $\begin{array}{l}\text { Lower } \\
\text { Bound }\end{array}$ & $\begin{array}{l}\text { Upper } \\
\text { Bound }\end{array}$ & \\
\hline M \& & OSS & & & & -.89 & 1.83 & $\begin{array}{l}\mathrm{Ho}_{2} \text { failed to be } \\
\text { Rejected }\end{array}$ \\
\hline & $\mathrm{BD}$ & $2.094^{*}$ & .571 & .001 & .73 & 3.45 & $\mathrm{Ho}_{2}$ Rejected \\
\hline $\mathrm{BD} \&$ & OSS & $1.625^{*}$ & .571 & .015 & .27 & 2.98 & $\mathrm{Ho}_{2}$ Rejected \\
\hline
\end{tabular}

*. The mean difference is significant at the 0.05 level. 

Ghana

From the results in Table 4, a higher statistically significant difference existed between the posttest mean score of students taught Biology practicals using TLA in Microscope and Biological Drawing $(10.41 \pm 1.99, p=.001)$ than Orientation, Section and Body Symmetry $(9.94 \pm 2.75, p=.691)$. Again, the results indicate a high statistically significant difference between the mean score of students taught Biology practicals using TLA in Biological Drawing and Orientation, Section \& Body Symmetry (8.31 \pm $2.02, p=.015)$

Since statistical test of significance only indicates whether results of treatment differ or not but does not indicate the size (magnitude) of the difference, the study computed the effect size (.149) of the treatment (TLA) on performance of students using analysis of Co-variance as indicated in Table 3. The effect size (.149) which was calculated and compared to Richardson (2011) and Cohen (1969) benchmarks for small (.0099), medium (.0588) and large (.1379) effect sizes, showed that the effect of TLA on students' performance was large.

\section{Research Question 2}

To what extent did MLA improve the performance of Second Year Home Economics students in three topics of biology practicals in two districts of Oti Region?

The above research question had a corresponding null hypothesis $\left(\mathrm{Ho}_{2}\right)$ stated as "there is no statistically significant difference among the mean achievement scores of Second Year Home Economics students taught Biology practicals using MLA in Microscope, Orientation, Section \& Body Symmetry and Biological Drawing" was answered by the findings of the statistical analysis of pretest and posttest scores of students in school 'B' as presented in Table 5 and 6.

Table 5: Students' performance in SKbBPCs before MLA $(\mathrm{N}=18)$

\begin{tabular}{ccccc}
\hline & Variable & Mean & Std. Deviation & Std. Error \\
\cline { 2 - 5 } \multirow{4}{*}{ Pretest } & M & 4.28 & 1.776 & .419 \\
& OSS & 4.61 & 2.004 & .472 \\
& BD & 2.67 & 2.890 & .681 \\
\hline
\end{tabular}

Table 6: Students' performance in SKbBPCs after MLA $(\mathrm{N}=18)$

\begin{tabular}{lcccc}
\hline \multirow{4}{*}{ Posttest } & Variable & Mean & Std. Deviation & Std. Error \\
\cline { 2 - 5 } & M & 11.06 & 2.127 & .501 \\
& OSS & 11.22 & 2.602 & .613 \\
\hline
\end{tabular}

The null research hypothesis $\left(\mathrm{Ho}_{2}\right)$ was also answered by one-way ANCOVA as indicated in Table 7 .

Table 7: Effect of MLA on students' performance in three topics of biology practicals

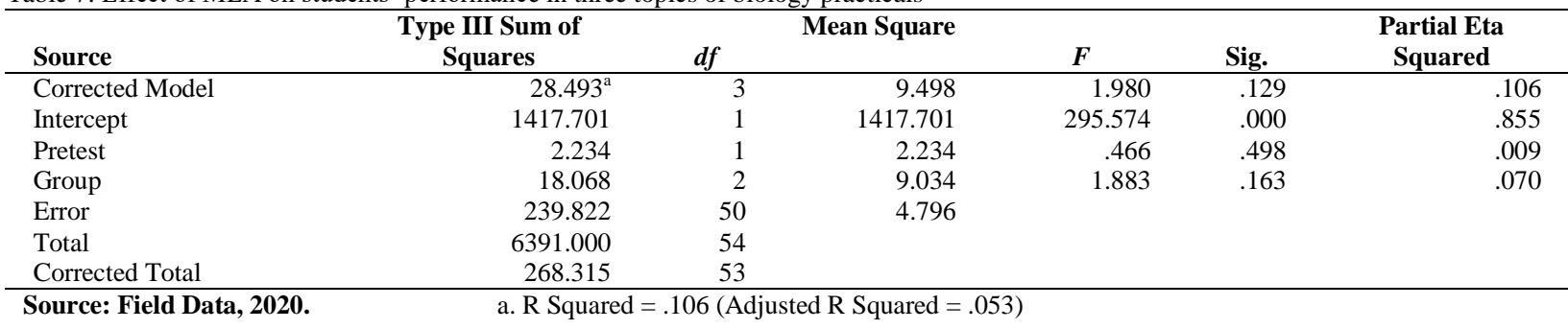

From Table 7, it was revealed that an $F(2,53) 1.883$ was not significant with a value of .163 at 0.05 alpha level. On this basis, the null hypothesis $\left(\mathrm{Ho}_{2}\right)$ was accepted and this implies that there is no statistically significant difference among the mean achievement scores of Second Year Home Economics students taught Biology practicals using MLA in Microscope, Orientation, Section \& Body Symmetry and Biological Drawing.

Again, Table 7 revealed an effect size of .07 which implies that the magnitude of the treatment (MLA) on students' performance is between medium (.0588) and large (.1379) according to Richardson (2011) and Cohen (1969) benchmarks for effect size.

\section{Research Question 3}

What is the effect of the combination of TLA and MLA on Second Year Home Economics students' performance in three topics of biology practicals in two Districts of Oti Region?

To answer this research question, results from statistical analysis of pretest and posttest scores of students of School ' $A$ ' who were taught biology practicals by Blended Approach was computed and presented. 
Impact of Blended Approach on Second Year Home Economics Students' Biology Practical Achievement in Two Districts of Oti Region, Ghana

Table 8: Students' performance in SKbBPCs before BA $(\mathrm{N}=30)$

\begin{tabular}{lllll}
\hline & & & & Std. Error \\
& Variable & Mean & Std. Deviation & \\
\cline { 2 - 5 } Pretest & M & 3.73 & 1.874 & .342 \\
& OSS & 4.93 & 2.033 & .371 \\
& BD & 4.10 & 1.517 & .277 \\
\hline
\end{tabular}

Table 9: Students' performance in SKbBPCs after BA $(\mathrm{N}=30)$

\begin{tabular}{lllll}
\hline \multirow{7}{*}{ Posttest } & Variable & Mean & Std. Deviation & Std. Error \\
\cline { 2 - 5 } & M & 12.67 & 2.564 & .468 \\
& OSS & 12.93 & 2.599 & .474 \\
& BD & 10.43 & 1.654 & .302 \\
\hline
\end{tabular}

Again, the corresponding null hypothesis $\left(\mathrm{Ho}_{3}\right)$ :

"there is no statistically significant difference among the mean achievement scores of SHS2 Home Economics students taught Biology

practicals using a combination of MLA and TLA in Microscope, Orientation, Section \& Body Symmetry and Biological Drawing" was tested by Analysis of Co-Variance (ANCOVA).

Table 10: Effect of BA on students' performance in three topics of biology practicals

\begin{tabular}{|c|c|c|c|c|c|c|}
\hline & Type III Sum of Squares & & Mean Square & & & Partial Eta Squared \\
\hline Source & & $d f$ & & $F$ & Sig. & \\
\hline Corrected Model & $126.893^{\mathrm{a}}$ & 3 & 42.298 & 8.046 & .000 & .219 \\
\hline Intercept & 2266.615 & 1 & 2266.615 & 431.167 & .000 & .834 \\
\hline Pretest & 13.804 & 1 & 13.804 & 2.626 & .109 & .030 \\
\hline Group & 119.716 & 2 & 59.858 & 11.386 & .000 & .209 \\
\hline Error & 452.096 & 86 & 5.257 & & & \\
\hline Total & 13563.000 & 90 & & & & \\
\hline Corrected Total & 578.989 & 89 & & & & \\
\hline
\end{tabular}

a. $\mathrm{R}$ Squared $=.219$ (Adjusted R Squared $=.192$ )

The Table 10, revealed an $F(1,89) 11.386$ was highly significant with a value of .00 at 0.05 alpha level. This implies that, the null hypothesis $\left(\mathrm{Ho}_{3}\right)$ was not supported $(.00<0.05)$ and hence rejected. Thus, there is a statistically significant difference among the mean achievement scores of Second Year Home Economics students taught Biology practicals using a combination of MLA and TLA in Microscope, Orientation, Section \& Body Symmetry and Biological Drawing.
To this, a follow-up of the posttest mean score test was carried out and the result as indicated in Table 11 showed that there is a high statistically significant mean difference between the posttest mean score of the students in Microscope and Biological Drawing $(12.67 \pm 2.56, p=.001)$ than Orientation, Section \& Body Symmetry $(12.93 \pm 2.59, p=.896)$. Again, there was a higher statistically significant difference between the mean score of the students in Biological Drawing and Orientation, Section \& Body Symmetry $(10.43 \pm 1.65, p=.000)$.

Table 11: Tukey Post Hoc Multiple Comparison of Significance of Variable Mean Scores

\begin{tabular}{|c|c|c|c|c|c|c|c|}
\hline \multirow{2}{*}{\multicolumn{2}{|c|}{ Comparisons }} & \multirow[b]{2}{*}{ Mean Difference } & \multirow[b]{2}{*}{ Std. Error } & \multirow[b]{2}{*}{ Sig. } & \multicolumn{2}{|c|}{$95 \%$ Confidence Interval } & \multirow[b]{2}{*}{ Remark } \\
\hline & & & & & $\begin{array}{l}\text { Lower } \\
\text { Bound }\end{array}$ & $\begin{array}{l}\text { Upper } \\
\text { Bound }\end{array}$ & \\
\hline \multirow[t]{2}{*}{ M \& } & OSS & -.267 & .598 & .896 & -1.69 & 1.16 & $\mathrm{Ho}_{4}$ failed to be Rejected \\
\hline & $\mathrm{BD}$ & $2.233^{*}$ & .598 & .001 & .81 & 3.66 & $\mathrm{Ho}_{4}$ Rejected \\
\hline $\mathrm{BD} \&$ & OSS & $2.500^{*}$ & .598 & .000 & 1.08 & 3.92 & $\mathrm{Ho}_{4}$ Rejected \\
\hline
\end{tabular}

*. The mean difference is significant at the 0.05 level.

Based on the effect size calculated in Table 10 (.209), and the fact that this magnitude is very large according to effect size benchmarks as proposed by Richardson (2011) and Cohen (1969) implies that the treatment (BA) on students' biology practical performance has accounted for higher improvement than TLA and also MLA.

These findings agree with that of Scott, Veitch, Gadegaard, Mughal, Norman and Welsh (2017) when they posited that the use of Blended approach in teaching biology practicals help to improve grades of students significantly with a concomitant increase in the number of ' $A$ ' grades obtained. To Yustina, Syafii and Vebrianto (2020), the use of blended approach among other teaching methods helps preservice biology teachers to significantly improve their performance in Biology.

Also, the findings of the study support Hinampas, Murillo, Tan and Layosa (2018) when they posited that the use of Blended Approach helps to improve 
students' academic achievement in science laboratories because it promotes a large variety of teaching styles as well as learning preferences (Cockerill, Comeau, Lee, \& Vinayata, 2015).

\section{Conclusions}

Based on the results of the finding, Blended Approach which involved Traditional Laboratory Approach and Multimedia Laboratory Approach in teaching biology practicals to Second Year Home Economics students had significant positive impact on their performance. To this, there is a need for Biology teachers to improve upon their ICT Skills and Biology practical experiences which includes Practical Content Knowledge (PCK) and Practical Pedagogical Knowledge (PPK) so that they can offer students efficient Teacher-Student Learning Support (TSLS) and consequently make good use of instructional time.

In addition, teachers who teach Biology must adjust to the use of Multimedia Laboratory Approach (MLA) in teaching practicals because it goes beyond the confines of the school settings and keep students active while outside the school or laboratory environment. Nonetheless, MLA should not be a substitute for TLA.

\section{Recommendations}

From the results of the findings, the study recommends that the Ghana Education Service Directorate for Senior High Schools in the Oti Region should do the following:

1) Organize seminars for Biology teachers on how to use the BA which combines MLA and TLA.

2) Build teachers capacity in ICT skills so that they would be able to teach Biology practicals using MLA.

3) Engage experience biology teachers to prepare biology practical lessons using Multimedia Laboratory Approach on selected topics and make it available to Biology teachers as a resource material.

4) Encourage Biology teacher training institutions to focus on ICT pedagogical integration in teaching practicals and likewise the use of BA.

5) Provide more ICT tools and ICT friendly environment that would help support the use of Blended Approach in teaching students Biology practicals.

\section{Acknowledgements}

We appreciate the enormous efforts of teachers and students involved in this study.

\section{References}

1. Agyei, D. D., \& Voogt, J. (2011a). ICT use in the teaching of mathematics: Implications for professional development of pre-service teachers in Ghana. Education and Information Technologies, 16(4), 423-439.

2. Agyei, D. D., \& Voogt, J. (2011b). Exploring the potential of the Will Skill Tool model in Ghana: Predicting prospective and practicing teachers' use of technology. Computers \& Education, 56(1), 91-100.

3. Al-Qahtani, A. A.Y., \& Higgins, S. E. (2013). Effects of traditional, blended and e-learning on students. Journal of Computer Assisted Learning, 29 (3), 220-234. https://doi.org/10.1111/j.1365-2729.2012.00490.x

4. Black, A. (2010). Gen Y: Who they are and how they learn. Educational Horizons, 88, 92-101.

5. Boelens, R., Van Laer, S., De Wever, B., \& Elen, J. (2015). Blended learning in adult education: towards a definition of blended learning. Retrieved from http://www.iwt-alo.be/wpcontent/uploads/2015/08/01-Project-report-Blended-learningin-adult-education-towards-a-definition-of-blendedlearning.pdf

6. Chism, N., Jones, C., Macce, B., \& Mountford, R. (1989). Teaching at the Ohio State University: A handbook. Columbus, OH: Ohio State University, Center for teaching Excellence.

7. Clark, J. (2003). Practical activities: What science teaching can learn from primary classrooms? Retrieved from https://www.aare.edu.au/03pap/c/a03570pdf

8. Cockerill, M., Comeau, T., Lee, T. H., \& Vinayak, J. (2015). Utilizing Video Multimedia Tools in Biology Labs, Project EL08.

9. Cohen, J. (1969). Statistical power analysis for the behavioural sciences. New York: New York

10. Cunningham, C. M., \& Kelly, G.J. (2017). Epistemic practices of engineering for education. Science Education, 101(3), 486-505.

11. Dechsri, P., Jones, L. L., \& Heikkmen, H. W. (1997). Effect of a laboratory Manual Design Incorporating Visual Information - Processing Aids on students learning and attitude. Journal of Research in Science Teaching, 34 (9), 891-904.

12. Duran, M., \& Ozdemir, O. (2009). A qualitative study on the effect of learners' scientific processing skills on their attitudes towards science $\left(1^{\text {st }}\right.$ International Congress of Educational Research). Canakkale: Canakkale University press.

13. Graham, C. R. (2013). Emerging practice and research in blended learning. In M. G. Moore (Ed.), Handbook of Distance Education (3rd ed., pp. 33-350). New York, NY: Routledge.

14. Häse, F., Roch, L. M., \& Aspuru-Guzik, A. (2019). NextGeneration Experimentation with self-Driving Laboratories. Trends in Chemistry, 1(3), 282-291. https://doi.org/10.1016/j.trechm.2019.02.007.

15. Hinampas, R. T., Murillo, C. R., Tan, D. A., \& Layosa, R. U. (2018). Blended Learning Approach: Effect on Students' Academic Achievement and Practical Skills in Science Laboratories. International Journal of Scientific \& Technology Research, 7 (11), 63-69.

16. Huang, S. L. (2006). An assessment of Science Teachers perception of Secondary School Environments in Taiwan. International Journal of Science Education, 28 (1), 25- 44.

17. Johnson, D. W., Johnson, R. T., \& Smith, K. A. (1991) Active learning: cooperation in the college classroom. Edina, MN: Interaction Book Company.

18. Kareem, A. A. (2018). The use of Multimedia in Teaching Biology and Its Impact on students Learning Outcomes. The Eurasia Proceedings of Educational and Social Sciences, 9, 157-165.Retrieved from https://dergipark.org.tr/en/pub/epess/isue/38900/457937

19. Nurhikmah, H., Tahmir, S., Junda, M., \& Bena, B. A. N (2018). Blended Learning Media in Biology classroom. Journal of Physics: conference series, 1028. https://doi.org/10.1088/1742-6596/1028/1/012027

20. Richardson, J.T. E. (2011). Eta squared and partial eta squared as measurements of effect size in educational 
research. Educational Research Review, 6,135-147

21. Scott, P. H., Veitch, N. J., Gadegaard, H., Mughal, M. Norman, G., \& Welsh, M. (2017). Enhancing theoretical understanding of practical biology course using active and self-directed learning strategies. Journal of Biological Education, 52(2), 184-195. https://doi.org/10.1080/00219266.2017.1293557

22. Singh, H., \& Reed, C. (2001). Achieving success with Blended Learning. Central software. ASTD State of the Industry Report. American Society for Training and Development.

23. Supiano, B. (2018). Traditional Teaching May Deepen Inequality. Can a Different Approach Fix it? - The Chronicle of Higher Education Retrieved from https://www.chronicle.com/article/Traditional-TeachingMay/243339

24. Trowbridge, L. W., Bybee, R. W., \& Powell, J. C. (2004). Teaching Secondary School Science: Strategies for
Developing Scientific Literacy. (8th ed.). Upper Saddle, New Jersey: Pearson Education, LUC.

25. Ümit, I., \& Haran, A. (2012). The Effect of Blended Learning Model on High School Students Biology Achievement and on their Attitudes towards the internet. The Turkish Online Journal of Educational Technology, 11(2), 228-237.

26. Umoke, J. C., \& Nwafor, C. C (2014). Effect of Instructional Simulation on Secondary School Students' Achievement in Biology. Journal of Education and Practice, 19 (5), 101-110.

27. White, H., \& Sabarwal, S. (2014). Quasi-experimental Design and Methods, Methodological Briefs:Impact Evaluation 8, no.8. Florence: UNICEF Office of Research.

28. Yustina, W., Syatii, R., \& Vebrianto, R. (2020). The Effects of Blended Learning and Project-Based Learning on Preservice Biology Teachers Creative Thinking through Online Learning in the Covid-19 pandemic. Journal Pendidikan IPA Indonesia, 9 (3), https://doi.org/10.15294/jpii.v9i3.24706 